Document downloaded from:

http://hdl.handle.net/10251/47019

This paper must be cited as:

Estornell Cremades, J.; Ruiz Fernández, LA.; Velázquez Martí, B.; Fernández Sarriá, A. (2011). Estimation of shrub biomass by airborne LiDAR data in small forest stands. Forest Ecology and Management. 262(9):1697-1703. doi:10.1016/j.foreco.2011.07.026.

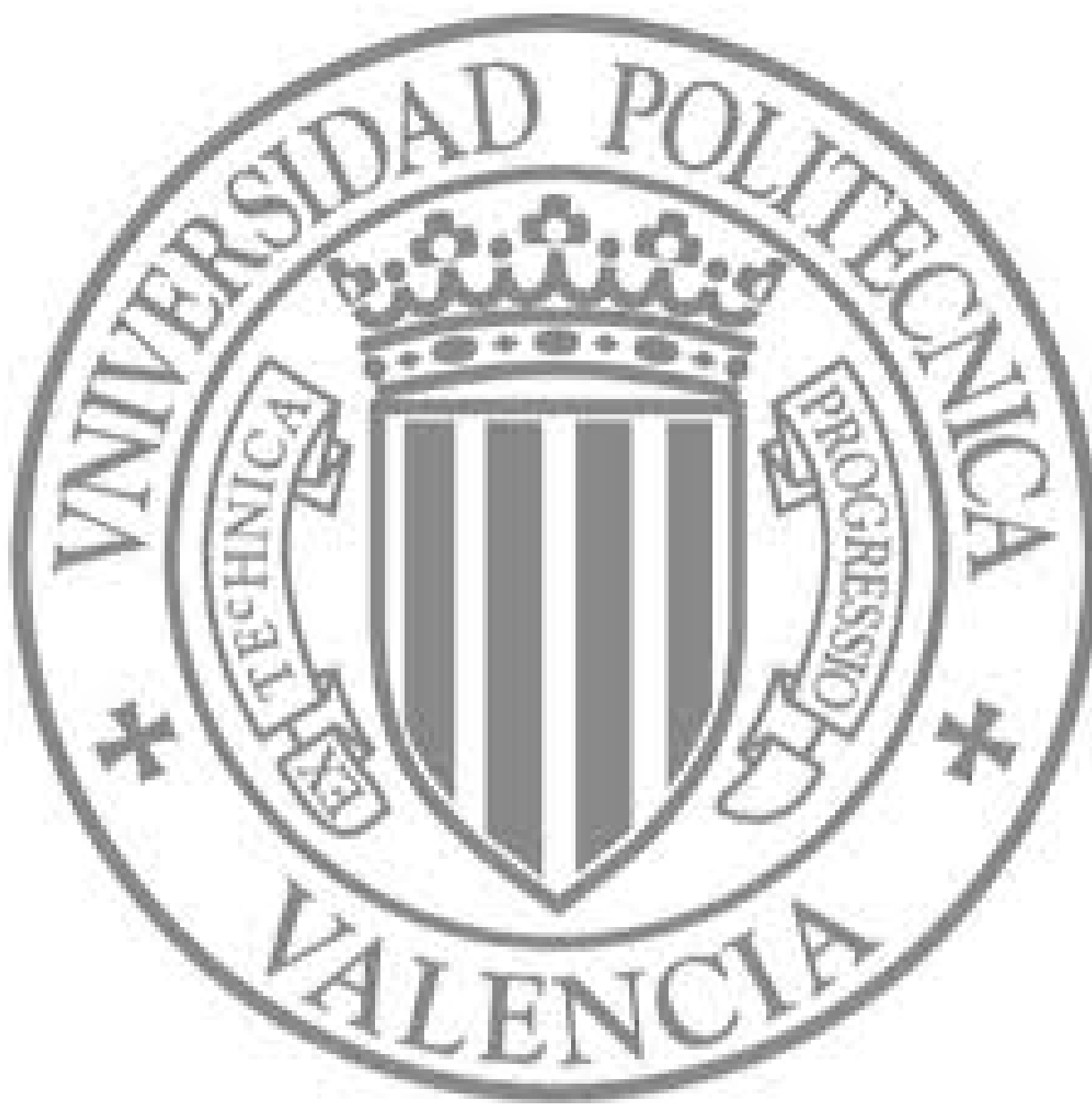

The final publication is available at

http://dx.doi.org/10.1016/j.foreco.2011.07.026

Copyright Elsevier 


\title{
ESTIMATION OF SHRUB BIOMASS BY AIRBORNE LIDAR DATA IN SMALL FOREST STANDS
}

\author{
*Estornell, J., *Ruiz, L. A., **Velazquez-Marti, B., *Fernández-Sarría, A. \\ *Departamento de Ingeniería Cartográfica Geodesia y Fotogrametría \\ ** Departamento de Ingeniería Rural y Agroalimentaria \\ Universitat Politècnica de València. Camino de Vera s/n 46701 Valencia (Spain) \\ e-mail:jaescre@cgf.upv.es
}

\begin{abstract}
The presence of shrub vegetation is very significant in Mediterranean ecosystems. However, the difficulty involved in shrub management and the lack of information about behavior of this vegetation means that these areas are often left out of spatial planning projects. Airborne LiDAR (Light Detection And Ranging) has been used successfully in forestry to estimate dendrometric and dasometric variables that allow to characterize forest structure. In contrast, little research has focused on shrub vegetation. The objective of this study was to estimate dry biomass of shrub vegetation in 83 stands of radius $0.5 \mathrm{~m}$ using variables derived from LiDAR data. Dominant species was Quercus coccifera, one of the most characteristic species of the Mediterranean forests. Density of LiDAR data in the analyzed stands varied from 2 points $/ \mathrm{m}^{2}$ to 16 points $/ \mathrm{m}^{2}$, being the average 8 points $/ \mathrm{m}^{2}$ and the standard deviation 4.5 points $/ \mathrm{m}^{2}$. Under these conditions, predictions of biomass were performed calculating the mean height, the maximum height and the percentile values $80^{\text {th }}, 90^{\text {th }}$, and $95^{\text {th }}$ derived from LiDAR in concentric areas whose radius varied from 0.50 to $3.5 \mathrm{~m}$ from the centre of the stand. The maximum $\mathrm{R}^{2}$ and the minimum RMSE for dry biomass estimations were obtained when the percentile $95^{\text {th }}$ of LiDAR data was calculated in an area of radius $1.5 \mathrm{~m}$, being 0.48 and $1.45 \mathrm{~kg}$, respectively. For this radius, it was found that for the stands $(n=39)$ where the DTM is calculated with high accuracy (RMSE lower than $0.20 \mathrm{~m}$ ) and with a high density of LiDAR data (more than 8 points $/ \mathrm{m}^{2}$ ) the $\mathrm{R}^{2}$ value was 0.73 . These results show the possibility of estimating shrub biomass in small areas when the density of LiDAR data is high and errors associated to the DTM are low. These results would allow us to improve the knowledge about shrub behavior avoiding the cost of field measurements and clear cutting actions.
\end{abstract}

Keywords: LiDAR, Forest management, Shrub, DTM, biomass 


\section{Introduction}

LiDAR system has been widely used in forestry to estimate dendrometric and dasometric variables such as height, biomass and tree volume (Zimble et al., 2003; Andersen et al., 2005; Hall et al., 2008; Li et al., 2008). Airborne laser scanning systems are found on the measurement of the time delay from pulse emission by an airborne sensor, to its return after reaching the earth's surface. These data contain coordinates of points where the reflections take place, as if they occur on ground as in any object above it, such as vegetation and buildings. Applying algorithms (ground filters) that allow to select points belonging to the ground and reject those above this surface, a digital terrain model (DTM) is calculated. With non-ground points a digital surface model (DSM) can be computed. The difference between DSM and DTM generate the normalized DSM. This surface contains the heights of all overlying features, named canopy height model (CHM) when includes vegetation heights. Raw LiDAR data and the DTM can be overlapped to convert point elevations into heights above ground. From these data a variety of statistical parameters, which describe height distribution of these points, can be derived to be used in the regression models for estimating height, biomass, volume ( Næsset 2004; Van Aardt et al., 2006, Li et al., 2008).

Previous researches have demonstrated the ability of LiDAR data to predict variables that characterize forests (Maltamo et al., 2004; Popescu et al., 2007; García et al., 2010). For this, two methodologies can be developed (Hyyppä et al., 2008): estimation of dasometric variables calculating regression models between field data and statistics derived from LiDAR data in plots-stands (Nelson et al., 1998; Naesset et al., 2004; Pascual et al., 2008; Li et al.,2008; García et al.,2010); and studies focused on the estimation of dendrometric variables being necessary a previous delineation of the tree crown (Hyyppä et al., 2001; Holmgren et al., 2003; Persson et al., 2002; Maltamo et al., 2004; Popescu, 2007; Forzieri et al., 2009). In contrast, little research has been conducted in shrub areas because their inherent difficulties (low height and uniform surface). Other reason can be found in the difficulty of measuring variables to characterize this vegetation to be correlated with LiDAR. For this, it is necessary either to cut off shrubs to obtain field data or assuming simple geometric shapes as a spheroid or cylinder that ignore complex plant architecture (Loudermilk et al., 2009; Velázquez 
et al., 2010). For this reason, the development of new tools that allow for a better knowledge of these areas using simple and non-destructive techniques is necessary. The reverse can be found for tree studies, as there are allometric equations that allow to estimate dendrometric variables from simple measurements carried out at field. In addition, unlike forests, there is less interest in the study of shrub vegetation from an economic point of view. Nevertheless, shrub vegetation areas show a relevant importance in environmental studies because they prevent soil erosion and desertification (Rango et al., 2000); contribute to managing the wildlife habitat (Mundt et al., 2006; Martinuzzi et al., 2009); contribute to creating fuel-type maps for better accuracy in fire behavior modeling (Riaño et al., 2007; Mutlu et al., 2008); represent important CO2 sinks; and help refill aquifers (Mikšys et al., 2007; Velázquez et al., 2010).

Studies of shrub vegetation with LiDAR data are commonly focused on the generation of species maps and on the estimation of shrub heights. In the first case, multispectral images and LiDAR data are often mixed to improve classifications of vegetation species (Hill and Thomson 2005; Mundt et al. 2006; Su and Bork 2007; Mutlu et al. 2008). The combination of both sources of data was also applied to improve the accuracy of a DTM (Rango et al. 2000; Riaño et al. 2007). As far shrub height is concerned, it was reported that when this vegetation is mixed with old growth trees the accuracy of shrub height estimation decreases as laser beams cannot penetrate the canopy enough, not reaching shrub layer. To improve these results it would be necessary considering a higher point density (Su and Bork, 2007). In this study, it was reported that while the value of $\mathrm{R}^{2}$ for height tree estimations was greater than 0.90 , for shrub vegetation did not reach 0.21 , what indicates the restrictions of LiDAR data to predict shrub heights in these areas. These results can explain why most studies of shrub height are placed in open areas with low presence of trees.

In general, LiDAR data produce underestimation of shrub vegetation (Gaveau and Hill, 2003; Hill y Thomson, 2005; Hopkinson et al., 2005; Su and Bork, 2007; Riaño et al., 2007). In these studies the plot was used as analysis area. The approach based on the extraction of individual plants show for this vegetation a high complexity because shrubs occupies a continuous surface in which crowns cannot be distinguished as it occurs in trees. For this reason, when shrub heights measured at field are compared to 
LiDAR data, buffers can be used. This methodology consists on the selection of LiDAR data within a concentric area whose center is the point measured at field. Previous studies reported that the best correlations between field measurements and heights derived from LiDAR data were obtained when a buffer of radius $1.5 \mathrm{~m}$ with center the point measured at center of the stand was used (Streutker and Glenn, 2006; Estornell et al., 2011). In these studies it was demonstrated that the accuracy of the DTM was a factor to be considered because the low differences in height between the vegetation and ground makes more difficult to separate from all LiDAR data, those belonging to the ground. Errors in the filtering processing can produce an underestimation or overestimation of shrub height. Meng et al., (2010) reported that low vegetation is often ignored by ground filters. Therefore, before predicting shrub parameters, it would be necessary to assess the accuracy of a DTM calculated in areas occupied by shrub vegetation with high slopes (Estornell et al., 2010).

In contrast, the accuracy of a DTM is less relevant in tree analysis as the differences in height between the ground and the trees are larger and LiDAR data associated to the ground or undergrowth are often removed (Popescu et al., 2002; Naesset, 2004; Kim et al., 2009). According to Streutker and Glenn (2006) the selection of the radius is related to the horizontal accuracy of LiDAR data and errors of GPS system. In addition, Su and Bork (2006) reported DTM errors in areas with high slopes can generate errors in herbaceous studies. On the other hand, scanning angle and the vegetation type also affect the accuracy of shrub height estimations. If vegetation is open and not dense the laser beam can reach ground producing low returns from vegetation (Hopkinson et al., 2005). Apart from these factors, it has been demonstrated that density of LiDAR data also affects the accuracy in the height shrub estimations for small areas.

Despite the previous studies, further research is needed to estimate shrub biomass, which is a relevant variable to evaluate landscape and ecosystems (Zheng et al., 2004), to estimate $\mathrm{CO}_{2}$ sinks and cellulosic material as a potential source of renewable energy (Popescu et al. 2007). Velazquez et al. (2010) developed dendrometric methodologies to calculate biomass volumes in shrub stands from simple measurements such as stand areas and dominant height of vegetation. Thus, as biomass is related to height, biomass could also be estimated from parameters derived of LiDAR data distribution. On the other hand, other studies revealed a high correlation between LiDAR data and biomass 
in old growth forests (Hyyppä e Inkinen, 1999, Nelson et al., 2004). Consequently, it will be necessary to analyze if statistics derived from LiDAR data allow to obtain good results for characterize shrub vegetation, analyzing if small sampling areas are suitable for these studies.

The objective of this research was to estimate shrub biomass in small stands (radius 0.5 m) and to generate a map of shrub biomass validated with field data. In addition, the factors accuracy of a DTM and density of LiDAR data will be evaluated. In this study it will also be analyzed the optimum radius that should be considered to select LiDAR data, which will be used to calculate parameters to estimate biomass in small stands.

\section{Materials and methods}

\subsection{Study area}

The $10 \mathrm{~km}^{2}$ study area is located in Chiva (Valencia, Spain), defined by a rectangle whose UTM coordinates $\mathrm{X}_{\text {maximum, }} \mathrm{Y}_{\text {maximum, }} \mathrm{X}_{\text {minimum, and }} \mathrm{Y}_{\text {minimum, }}$ are 689800 , 4376028,683800 , and 4373000, respectively (Fig. 1). The area is located in zone 30 in the European Datum 1950 reference system. It is a mountainous area with a predominance of Quercus coccifera (Fig. 2), one of the most typical species of the Mediterranean region (Takhtajan, 1986; Gómez et al., 1998). Other species can be found such as Rosmarinus officinalis, Ulex parviflorus, Cistus albidus L. and Erica multiflora $L$. These species are the most abundant in Mediterranean forests. The average percentage occupation is around 55\%. In contrast, there is a sub-area with trees occupying about 10\%. The altitude varies between 442 and 1000 meters, and the average slope is $45 \%$.

\subsection{LiDAR data.}

The LiDAR data were acquired during a flight in December 2007, using an Optech ALTM 2050 system. The technical parameters were: flight height $-700 \mathrm{~m}$ above ground; pulse frequency $-50 \mathrm{kHz}$; scan frequency $-47 \mathrm{~Hz}$; scan angle $- \pm 18^{\circ}$; speed flight $-70 \mathrm{~m} / \mathrm{s}$; swath width $-400 \mathrm{~m}$; distance between a scanning trajectory flight $300 \mathrm{~m}$; number of strips- 10 ; total points obtained for the test area $-78,919,301$; nominal pulse density -4 points $/ \mathrm{m}^{2}$; Number of echoes -2 . However, given that 10 overlapping flight lines were registered, some areas had a higher point density. For this 
reason, the average point density of the study area, considering both returns, was 8 points $/ \mathrm{m}^{2}$. More than $99 \%$ of the LiDAR values belonged to the first pulse. This could be caused by the small difference in height between the canopy of vegetation and the ground.

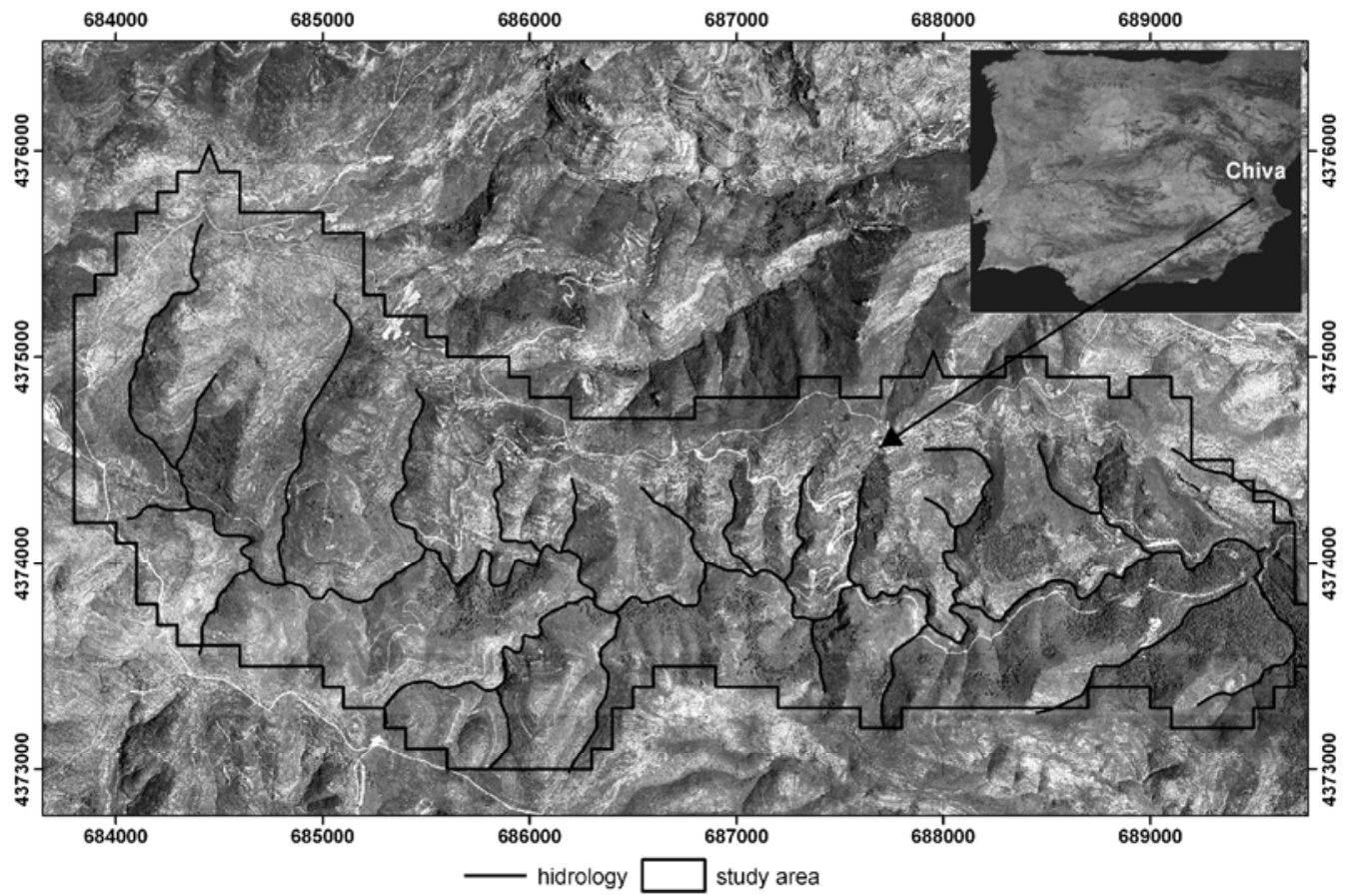

Figure 1. Location of study area in Chiva (Spain). The black polygon represents area surveyed with LiDAR.

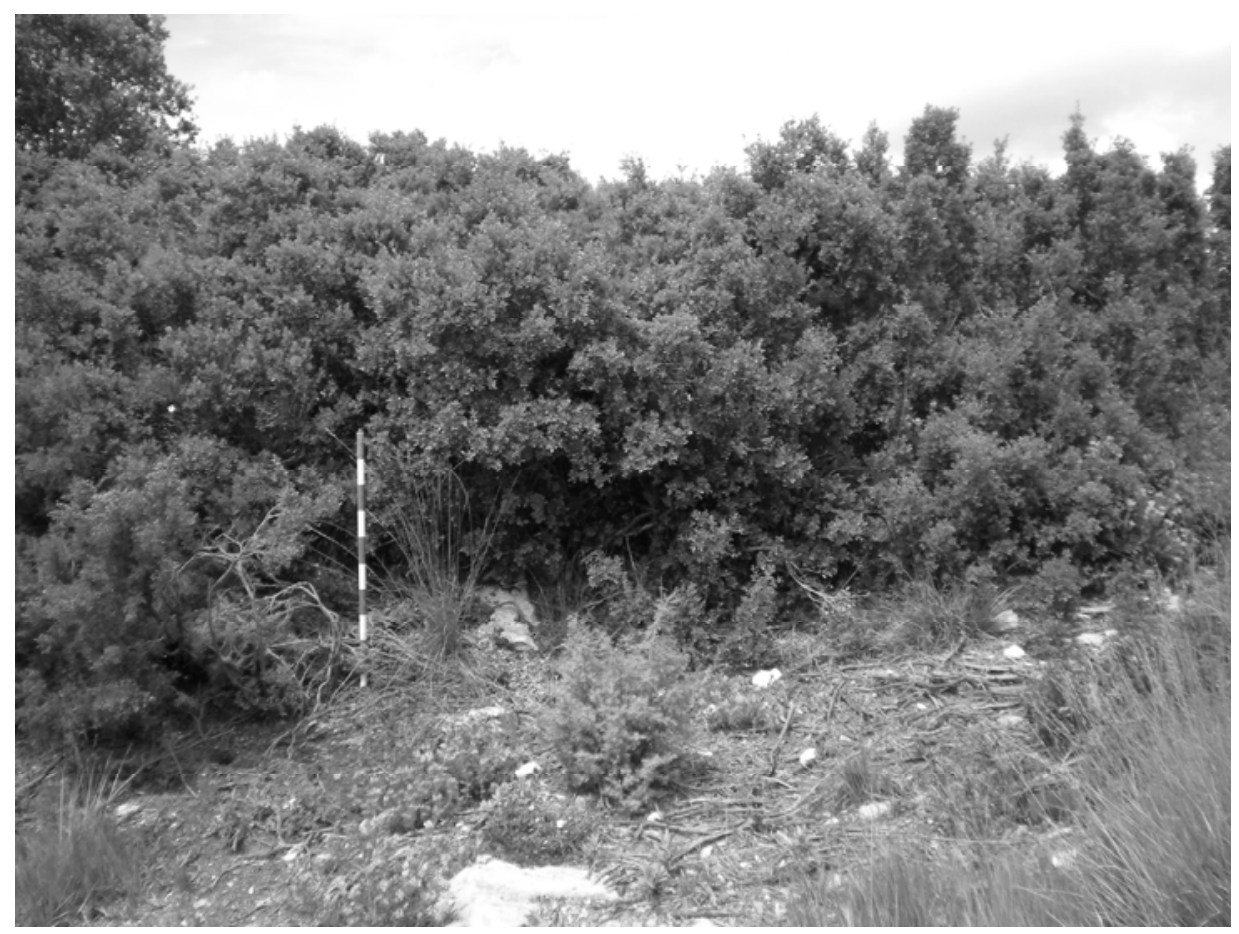

Figure 2. Study area photograph with dense presence of kermes oak (Quercus coccifera). 
To assess the altimetry accuracy of LiDAR data, 60 checkpoints were selected in flat areas without vegetation (Streutker and Glenn, 2006). Elevations measured using the RTK-GPS were compared with the average elevation of LiDAR points in a buffer radius of $0.5 \mathrm{~m}$ around the point measured. This radius was selected because the horizontal accuracy of LiDAR points was $0.5 \mathrm{~m}$ according to the specifications of the technical report of the vendor company. The RMSE of the two sets of measurements was $6 \mathrm{~cm}$. Similar results were obtained for some additional 23 points distributed in areas with an average slope of $40 \%$ without vegetation or any objects above the ground.

To compute the DTM from LiDAR data it is necessary to apply algorithms to eliminate points belonging to any object above the ground surface such as vegetation or buildings. To achieve this, we generated an IDL program based on iterative processes for selecting minimum elevations in decreasing windows and height thresholds for removing vegetation points (further information can be found in Estornell et al., 2010).

To evaluate the accuracy of the DTM, 1397 ground-surveyed checkpoints were distributed across the study area and randomly measured with an RTK-GPS system (Leica System 1200); thus making these independent validation data appropriate for assessing any global elevation bias in the DTM. Horizontal and vertical accuracy of the RTK-GPS system in terms of root mean square error (RMSE) value was $1 \mathrm{~cm}$ and $2 \mathrm{~cm}$ respectively, according to the technical specifications of the instrument. Average horizontal and vertical errors for the measured points were 1 and $1.5 \mathrm{~cm}$, respectively. The RTK-GPS system did not register any point whose error was greater than $5 \mathrm{~cm}$. The lowest RMSE was for analysis window sizes of 10, 5 and $2.5 \mathrm{~m}$ and height thresholds equal to, or greater than, $1.5 \mathrm{~m}$. These parameters produced a DTM with a mean signed error of $0.02 \mathrm{~m}$, a standard deviation of $0.19 \mathrm{~m}$, and an RMSE of $0.19 \mathrm{~m}$.

\subsection{Biomass field data}

Field sampling was performed immediately after the acquisition of LiDAR data along a period of up to 3 months. This temporal coincidence implied that the structure of vegetation remained invariable between the data acquisition and field sampling. Biomass of shrub vegetation was measured in 83 stands of radius $0.5 \mathrm{~m}$ randomly distributed across the study area in different bioclimatic layers (elevation), slope and aspect. Each stand was circular and the vegetation inside them was clear cut. In each 
clear cutting we counted the number of shrub plants inside the stand, identified the species, and measured the weight, length, and base diameter of stems for each plant. After applying a drying process for some individuals of each species, it was also obtained the dry weight of each clear cutting shrub. Adding for each stand the weight of each plant it was obtained the stand biomass to be correlate with LiDAR data. In the table 1 the statistics of dominant heights and biomass of stands can be observed.

Table 1. Statistics of height and biomass from field data in 83 stands occupied by shrub vegetation

\begin{tabular}{cccc}
\hline Statistic & Height $(\mathrm{m})$ & Wet biomass $(\mathrm{kg})$ & Dry biomass $(\mathrm{kg})$ \\
\hline Mean & 1.27 & 6.33 & 4.17 \\
Minimum & 0.80 & 1.67 & 0.99 \\
Maximum & 2.50 & 15.90 & 10.65 \\
Standard deviation & 0.29 & 2.96 & 1.98 \\
\hline
\end{tabular}

\subsection{Estimation of biomass}

To estimate the dry biomass of shrub vegetation, statistics derived from all LiDAR point cloud were obtained and used as explanatory variables in the regression models. For LiDAR data, the bare-earth surface elevation was first subtracted from each LiDAR point by using the DTM. In the selection of points within each stand of radius $0.5 \mathrm{~m}$, it was found that several stands had few points. Then, to increase the number of points, concentric areas whose center was the centre of each stand were considered to derive height statistics from LiDAR data (Streutker and Glenn, 2006; Estornell et al., 2011). These authors suggest that when the height shrubs measured at field are compared with heights derived from LiDAR data, maximum correlations were obtained when LiDAR data were selected in a concentric of radius $1.5 \mathrm{~m}$ and centre the stand. This result can be explained considering a set of factors that affect the accuracy of height shrub: density LiDAR data, error associated to DTM, type of vegetation, slope. Consequently, it was also analyzed for biomass, what radius was more suitable to extract statistics derived from LiDAR data to be correlated with biomass measured at field. For this, the followed radii were analyzed (in meters): $0.5,0.75,1,1.25,1.5,1.75,2,2.25,2.5,2.75$, 3, 3.25, and 3.5. For each radius and stand the maximum height from LiDAR data was calculated. Linear regression models were calculated and compared from the values of $\mathrm{R}^{2}$. Analyzing several radii allowed us to select other statistics and to analyze possible improvements in the estimations. The statistics computed were: mean height $\left(\mathrm{H}_{\text {mean }}\right)$, 
maximum height $\left(\mathrm{H}_{\max }\right)$, and percentiles $80^{\text {th }}\left(\mathrm{P}_{80}\right), 90^{\text {th }}\left(\mathrm{P}_{90}\right)$, and $95^{\text {th }}\left(\mathrm{P}_{95}\right)$. Linear and quadratic regressions were calculated and the values of $\mathrm{R}^{2}$ and RMSE were compared.

\subsection{Analyzed factors in the estimation of biomass}

It was also analyzed if the error associated to the DTM and the density of LiDAR data affect to the accuracy of dry biomass estimations in small stands. This analysis was performed considering the statistic of LiDAR data and the radius of the concentric area which produced the best estimations of above estimations of biomass.

To analyze the factor density in the prediction models, the density of LiDAR data in each stand was calculated. From these results, the stands were classified into two classes: density $>8$ points $/ \mathrm{m}^{2}(\mathrm{n}=47)$ and density $<8$ points $/ \mathrm{m}^{2}(\mathrm{n}=36)$. The mean density and standard deviation of the stands belonging to the first group were 12 points $/ \mathrm{m}^{2}$ and 4 points $/ \mathrm{m}^{2}$, respectively. For the second group the mean and the standard deviation were 4.36 points $/ \mathrm{m}^{2}$ and 1.79 points $/ \mathrm{m}^{2}$, respectively. The biomass for each group of stands was estimated and the values of $\mathrm{R}^{2}$ and RMSE were compared.

For studying how affects the error associated to DTM in the estimation of biomass, the differences between the coordinate $\mathrm{z}$ of each stand centre measured with GPS-RTK and the coordinate $\mathrm{z}$ of the DTM were calculated. Then, the stands were grouped into two classes. The stands whose differences were lower than $0.20 \mathrm{~m}$ in absolute value belonged to the first group $(n=52)$ and the stands with differences greater than $0.20 \mathrm{~m}$ in absolute value belonged to the second group $(n=31)$. The threshold of $0.20 \mathrm{~m}$ was the RMSE of the most accurate DTM computed. The biomass for each group of stands was estimated and the values of $\mathrm{R}^{2}$ and RMSE were compared.

Finally, all the above possible combinations were tested to analyze if the biomass estimation can be improved: stands with density greater and lower than 8 points $/ \mathrm{m}^{2}$ with stands with DTM error greater and lower than $0.20 \mathrm{~m}$. The biomass for each group of stands was estimated and the values of $\mathrm{R}^{2}$ and RMSE were compared. The variation of $\mathrm{R}^{2}$ for different radii in stands with point density higher than 8 points $/ \mathrm{m}^{2}$ was also studied. In addition, the DTM accuracy and the combination of both, DTM accuracy and point density factors, were also analyzed. 


\section{Results and discussion}

\subsection{Biomass estimation}

Firstly, it was compared dry biomass measured at field in stands of $0.75 \mathrm{~m}^{2}$ (radius $=$ $0.5 \mathrm{~m}$ ) and the maximum height of LiDAR data obtained in concentric areas with radius between 0.5 and $3.5 \mathrm{~m}$. As can be observed in the Figure 3, when LiDAR data are selected using the radii $1.25 \mathrm{~m}, 1.50 \mathrm{~m}$, and $1.75 \mathrm{~m}$ the highest determination coefficients were obtained $\left(\mathrm{R}^{2} 0.38-0.39\right)$. This finding is in line with previous researches in which the radius of $1.5 \mathrm{~m}$ was selected to calculate parameters derived from LiDAR data to estimate shrub height (Streutker and Glen, 2006; Estornell et al., 2010).

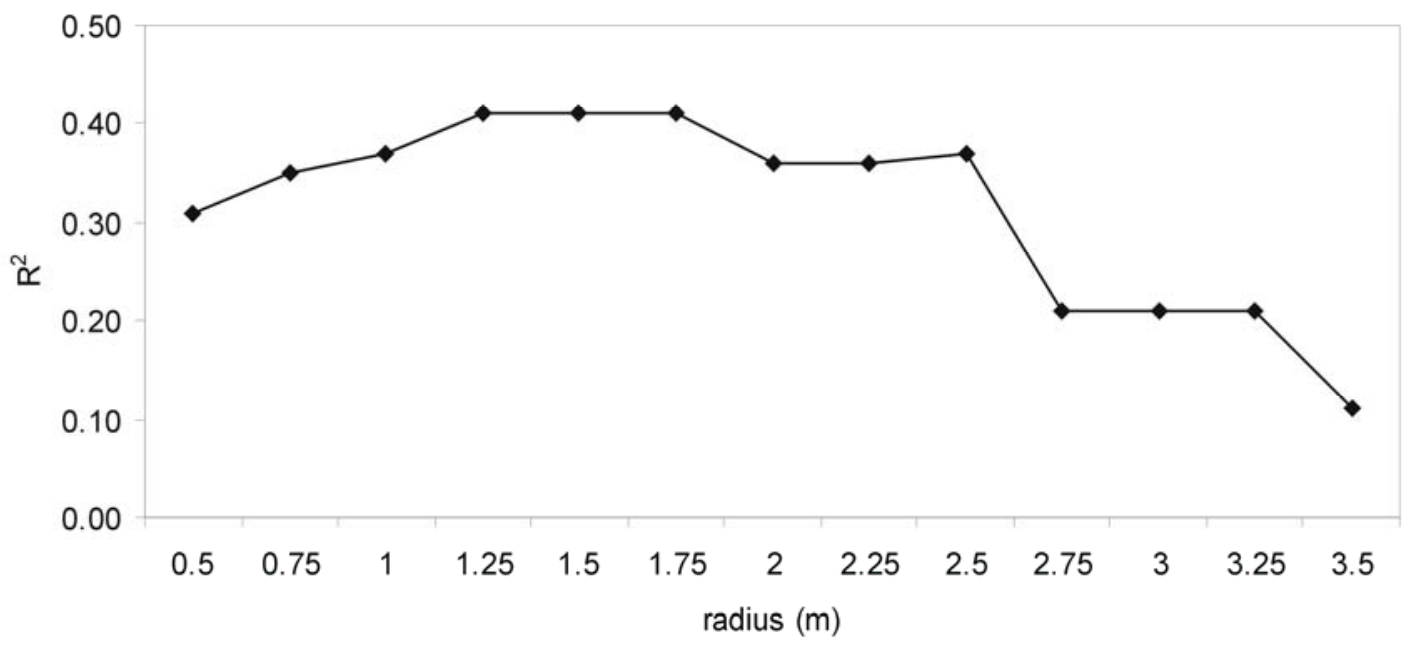

Figure 3. Determination coefficients $\left(\mathrm{R}^{2}\right)$ of linear regression models for estimating dry biomass considering the maximum LiDAR data in concentric areas of radius ranging from 0.5 to $3.5 \mathrm{~m}$ from the stand centre.

One of the disadvantages of selecting LiDAR data in small stands is the reduced number of points within each stand what produces that only one statistic can be calculated to be used in the prediction models (maximum height). The use of a concentric area of radius $1.5 \mathrm{~m}$ for selecting LiDAR data allowed us to analyze other statistics (Table 2). As can be observed, the maximum $\mathrm{R}^{2}$ was obtained when a quadratic model and the percentile $95^{\text {th }}$ were used $\left(R^{2}=0.48\right)$. The moderate values of $\mathrm{R}^{2}$ can be explained by the influence for these reduced areas of factors such as DTM errors, density of LiDAR data, accuracy of LiDAR data, vegetation species. This is 
demonstrated in the following analysis where better predictions are obtained when the density of LiDAR data is higher and the DTM errors are lower (Table 5)

Table 2. Estimations of dry biomass in 83 stands of radius $0.5 \mathrm{~m}$ considering LiDAR data from concentric areas of radius $1.5 \mathrm{~m}$, considering linear and quadratic regression models.

\begin{tabular}{cccccc}
\hline $\begin{array}{c}\text { Predicted } \\
\text { variable }(\mathrm{kg})\end{array}$ & $\begin{array}{c}\text { Explicative } \\
\text { variables }\end{array}$ & Models & $\mathrm{R}^{2}$ & P-value & RMSE $(\mathrm{kg})$ \\
\hline \multirow{2}{*}{ Mean height } & $\mathrm{y}=1.17+5.20 \mathrm{H}_{\text {mean }}$ & 0.37 & $<0.01$ & 1.60 \\
& & $\mathrm{y}=2.70+3.76 \mathrm{H}_{\text {mean }}{ }^{2}$ & 0.39 & $<0.01$ & 1.58 \\
& Percentile $80^{\text {th }}$ & $\mathrm{y}=0.84+4.14 \mathrm{P}_{80}$ & 0.42 & $<0.01$ & 1.54 \\
& & $\mathrm{y}=2.49+2.237 \mathrm{P}_{80}{ }^{2}$ & 0.46 & $<0.01$ & 1.49 \\
Dry biomass & Percentile 90 $0^{\text {th }}$ & $\mathrm{y}=0.57+3.98 \mathrm{P}_{90}$ & 0.43 & $<0.01$ & 1.51 \\
& & $\mathrm{y}=2.39+1.91 \mathrm{P}_{90}{ }^{2}$ & 0.48 & $<0.01$ & 1.46 \\
& \multirow{3}{*}{ Percentile 95 } & $\mathrm{y}=0.40+3.87 \mathrm{P}_{95}$ & 0.44 & $<0.01$ & 1.51 \\
& & $\mathrm{y}=2.34+1.72 \mathrm{P}_{95}{ }^{2}$ & 0.48 & $<0.01$ & 1.45 \\
& \multirow{2}{*}{ Maximum height } & $\mathrm{y}=0.39+3.22 \mathrm{H}_{\max }$ & 0.41 & $<0.01$ & 1.55 \\
& & $\mathrm{y}=2.31+1.29 \mathrm{H}_{\max }{ }^{2}$ & 0.45 & $<0.01$ & 1.49 \\
\hline
\end{tabular}

The obtained equations allow to predict biomass in stands of a radius $0.5 \mathrm{~m}$ considering statistics derived from LiDAR data in a radius of $1.5 \mathrm{~m}$. Considering that the areas where LiDAR data were extracted are homogenous, new equations to predict biomass in areas between 1 and $1.75 \mathrm{~m}$ radius could be obtained. It should be highlighted that these new equations and RMSE are proportional to those shown in table 2 with the same $\mathrm{R}^{2}$. This is due to the fact that biomass of areas with radius larger than $0.5 \mathrm{~m}$ could be calculated thanks to the proportionality that exists in the homogeneous areas. Since the vegetation type and density in the plot is homogeneous, biomass is essentially proportional to the plot area.

\subsection{Factors analyzed in the estimation of biomass}

To analyze if better results can be obtained for the prediction of biomass in stand of reduced area, the factors density of LiDAR data and error associated to DTM were studied. The table 3 shows better relationships between field biomass and LiDAR data when a density greater than 8 points $/ \mathrm{m}^{2}$ was used $\left(\mathrm{R}^{2}=0.68\right.$ and $\left.\mathrm{RMSE}=1.26 \mathrm{~kg}\right) . \mathrm{In}$ contrast, the correlations found for the stands with a density lower than 8 points $/ \mathrm{m}^{2}$ were lower $\left(\mathrm{R}^{2}=0.26\right.$ and $\left.\mathrm{RMSE}=1.55 \mathrm{~kg}\right)$. This result indicates that the point density 
is a factor to be considered to improve the estimation of biomass in stands of reduced area.

Table 3. Estimations of dry biomass in stands of 0.5 radius considering LiDAR data from concentric areas of radius $1.5 \mathrm{~m}$, with data density higher than 8 points $/ \mathrm{m}^{2}(\mathrm{n}=47)$ and lower than $(\mathrm{n}=36)$.

\begin{tabular}{cccccc}
\hline $\begin{array}{c}\text { Predicted } \\
\text { variable } \\
(\mathrm{kg})\end{array}$ & $\begin{array}{c}\text { Density } \\
\left(\text { points } / \mathrm{m}^{2}\right)\end{array}$ & $\begin{array}{c}\text { Explicative } \\
\text { variable }\end{array}$ & Models & $\mathrm{R}^{2}$ & RMSE (kg) \\
\hline $\begin{array}{c}\text { Dry } \\
\text { biomass }\end{array}$ & $\mathrm{d}<8$ & $\begin{array}{c}95 \text { percentile } \\
(\mathrm{n}=36) \\
95\end{array}$ & $\mathrm{y}=3.04+1.46 \mathrm{P}_{95}{ }^{2}$ & 0.26 & 1.55 \\
$(\mathrm{n}=47)$ & $\mathrm{d}>8$ & & & 0.68 & 1.26 \\
\hline
\end{tabular}

For DTM error factor, better relationships between field data biomass and LiDAR data were also found for stands with low error associated to DTM (Table 4). In this case, the values of $\mathrm{R}^{2}$ and RMSE were 0.66 and $1.24 \mathrm{~kg}$, respectively. This finding suggests the importance of computing an accurate DTM in areas occupied by shrub vegetation with high slopes. Therefore, before predicting shrub parameters, it would be necessary to assess the accuracy of a DTM selecting an algorithm and parameters that minimize these errors especially for these areas as low vegetation is often ignored by ground filters (Meng et al., 2010).

Table 4. Estimations of dry biomass in stands of 0.5 radius considering LiDAR data from concentric areas of radius $1.5 \mathrm{~m}$, with a DTM error lower than $0.20 \mathrm{~m}(\mathrm{n}=52)$ and greater than 0.20 $\mathrm{m}(\mathrm{n}=31)$.

\begin{tabular}{cccccc}
\hline $\begin{array}{c}\text { Predicted } \\
\text { variable } \\
(\mathrm{kg})\end{array}$ & $\begin{array}{c}\text { Explicative } \\
\text { variables }\end{array}$ & Modelo & $\mathrm{R}^{2}$ & P-value & RMSE (kg) \\
\hline $\begin{array}{c}\text { Dry } \\
\text { biomass }\end{array}$ & $\begin{array}{c}\text { percentile } 95^{\text {th }} \\
(\mathrm{n}=52)\end{array}$ & $\mathrm{y}=1.84+1.90 \mathrm{P}_{95^{2}}$ & 0.66 & $<0.01$ & 1.24 \\
& $\begin{array}{c}\text { percentile } 95^{\text {th }} \\
(\mathrm{n}=31)\end{array}$ & $\mathrm{y}=3.16+1.36 \mathrm{P}_{95^{2}}$ & 0.20 & $<0.01$ & 1.65 \\
\hline
\end{tabular}

In addition to the models shown, we proved that when the value of $0.15 \mathrm{~m}$ was selected as error associated to DTM to grouped the stands, better relationships were obtained being the values of $\mathrm{R}^{2}$ and RMSE, 0.73 and $1.16 \mathrm{~kg}(\mathrm{n}=40)$, respectively. This result reveals that good predictions of biomass in small stands can be obtained from LiDAR data for accurate DTM. However, for larger stands, this factor could be less important (Estornell et al., 2011). 
The combination of the above factors in predicting biomass was analyzed. As observed in the Table 5, the highest relationships were found for stands with density greater than 8 points $/ \mathrm{m}^{2}$ and DTM errors lower than $0.20 \mathrm{~m}(\mathrm{n}=39)$. The $\mathrm{R}^{2}$ and RMSE values were 0.73 and $1.21 \mathrm{~kg}$, respectively.

Table 5. Estimation of dry biomass in stands of 0.5 radius considering LiDAR data from concentric areas of radius $1.5 \mathrm{~m}$, combining stands with density greater and lower than 8 points $/ \mathrm{m}^{2}$ in stands with DTM errors greater and lower than $0.20 \mathrm{~m}$.

\begin{tabular}{|c|c|c|c|c|c|c|}
\hline Factors & $\mathrm{n}$ & Predicted variable $(\mathrm{kg})$ & Models & $\mathrm{R}^{2}$ & $\mathrm{P}$-value & RMSE (kg) \\
\hline $\begin{array}{c}\text { Density }>8 \text { points } / \mathrm{m}^{2} \\
\text { and DTM error }<0.20 \mathrm{~m}\end{array}$ & 39 & Dry biomass & $\mathrm{y}=1.53+2.07 \mathrm{P}_{95}{ }^{2}$ & 0.73 & $<0.01$ & 1.21 \\
\hline $\begin{array}{l}\text { Density }>8 \text { points } / \mathrm{m}^{2} \\
\text { and DTM error }>0.20 \mathrm{~m}\end{array}$ & 8 & Dry biomass & $\mathrm{y}=2.98+0.71 \mathrm{P}_{95}{ }^{2}$ & 0.09 & $<0.01$ & 1.44 \\
\hline $\begin{array}{l}\text { Density }<8 \text { points } / \mathrm{m}^{2} \\
\text { and DTM error }<0.20 \mathrm{~m}\end{array}$ & 13 & Dry biomass & $\mathrm{y}=2.83+1.01 \mathrm{P}_{95}{ }^{2}$ & 0.22 & $<0.01$ & 1.24 \\
\hline $\begin{array}{c}\text { Density }<8 \text { points } / \mathrm{m}^{2} \\
\text { and DTM error }>0.20 \mathrm{~m}\end{array}$ & 22 & Dry biomass & $y=3.22+1.66 P_{95}^{2}$ & 0.29 & $<0.01$ & 1.68 \\
\hline
\end{tabular}

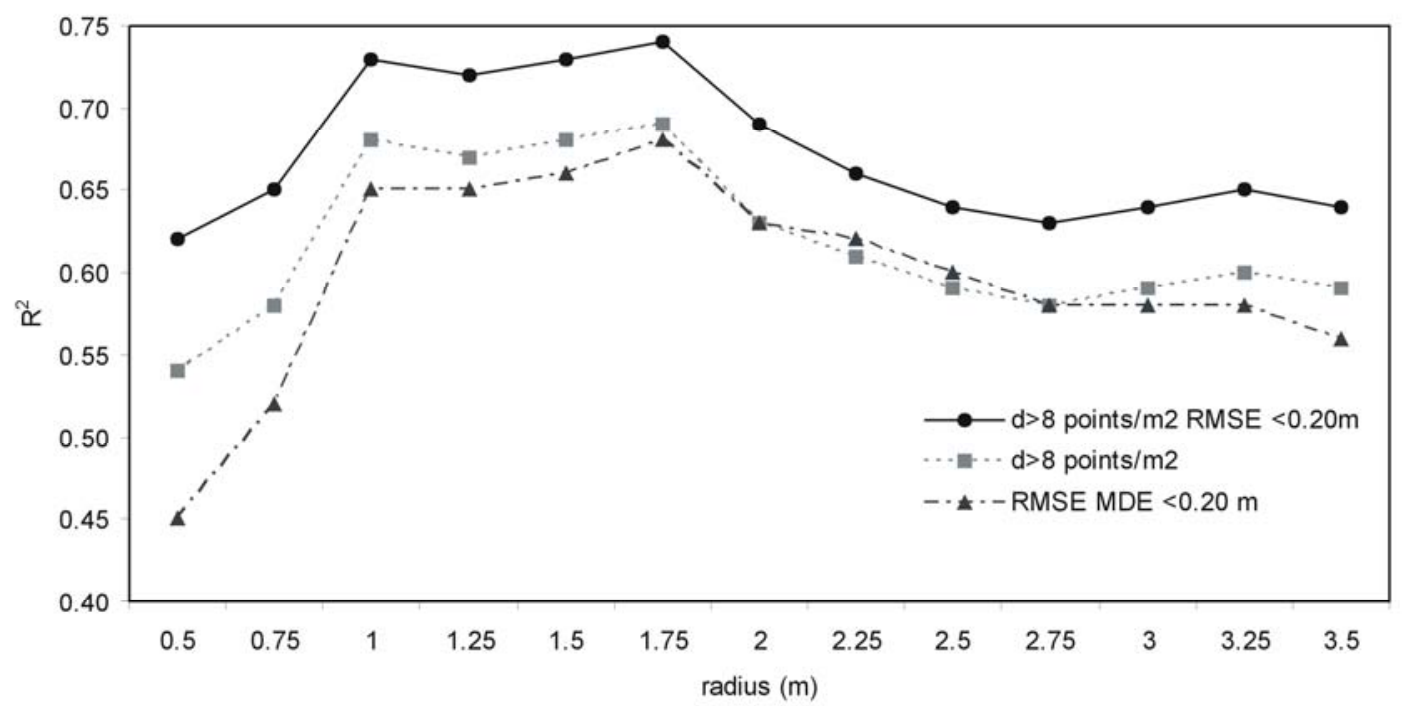

Figure 4. Determination coefficients $\left(\mathrm{R}^{2}\right)$ of quadratic regression models for estimating dry biomass considering the $95^{\text {th }}$ percentile of LiDAR data in concentric areas of radius ranging from 0.5 to $3.5 \mathrm{~m}$ from the stand centre, in stands with a DTM error lower than $0.20 \mathrm{~m}(\mathrm{n}=52)$, with data density higher than 8 points $/ \mathrm{m}^{2}(\mathrm{n}=47)$, combining both factors $(\mathrm{n}=39)$. 
As deduced from Figure 4, the optimal radius to correlate shrub biomass and LiDAR data is influenced not only by the point density, but also other factors such as the error associated to the computation of DTM should be considered. The maximum determination coefficient was obtained for stands with low RMSE in DTM computation $(\mathrm{RMSE}<0.20 \mathrm{~m})$ and density higher than 8 points $/ \mathrm{m} 2\left(\mathrm{R}^{2}=0.74\right)$. Under these conditions, radii lower than $1.5 \mathrm{~m}$ can be selected to extract LiDAR data.

\section{Conclusions}

In this study it was demonstrated that the best relationships between field biomass and LiDAR data were found when concentric areas of radius $1.5 \mathrm{~m}$ and centre of each stand were considered to calculate statistics derived from point cloud LiDAR. Although the values of $\mathrm{R}^{2}$ in the estimation of biomass were low for all stands, remarkable improvements were found when the predictions of biomass were performed for stands with density greater than 8 points $/ \mathrm{m}^{2}$ and/or DTM error lower than $0.20 \mathrm{~m}$. These findings reveal the possibility of using LiDAR data to predict biomass in small stands what can be very useful to study and management shrub vegetation in local areas. For these conditions, small radius could be used $(1 \mathrm{~m})$, close to the horizontal accuracy of LiDAR data. These results would allow us to improve the lack of information about shrub behavior avoiding the cost of field measurements and clear cutting actions. For this it would be necessary to acquire LiDAR data with high density and to use suitable algorithms to compute an accurate DTM. When these conditions are not met, larger stands should be considered to calculate several statistics derived from height distribution of LiDAR data and statistics derived from density profiles. In this case, to avoid to clear cutting all vegetation within these stands it would be necessary to select samples of the vegetation within them.

In our study, it has been demonstrated that optimal radius to correlate shrub height and LiDAR data is influenced not only by the point density, but also other factors, such as the error associated to the DTM computation, should be considered. These findings improve the observations of Streutker and Glenn (2006), who pointed that the optimal radius of $1.5 \mathrm{~m}$ was influenced only by the horizontal LiDAR accuracy and general accuracy of GPS unit. Radii lower than $1.5 \mathrm{~m}$ can be selected in areas with low RMSE in DTM computation (RMSE $<0.20 \mathrm{~m}$ ) and density higher than 8 points $/ \mathrm{m}^{2}$. 


\section{References}

Andersen, H-E., McGaughey, R.J., Reutebuch, S.E., 2005. Estimating forest canopy fuel parameters using LiDAR data. Rem. Sens. Environ. 94, 441-449.

Bork, E.W., Su, J.G., 2007. Integrating LiDAR data and multispectral imagery for enhanced classification of rangeland vegetation: A meta analysis. Rem. Sens. Environ. $111,11-24$.

Estornell, J., Ruiz, L.A., Velazquez-Marti, B., 2011. Study of shrub cover and height using LiDAR data in a Mediterranean area. For. Sci. 57, 171-179.

Estornell, J., Ruiz, L. A., Velázquez-Martí, B., Hermosilla, T. 2010. Analysis of the factors affecting LiDAR DTM accuracy in a steep shrub area. Int. J. Digital Earth, doi:10.1080/17538947.2010.533201

Forzieri, G., Guarnieri, L., Vivoni, E.R., Castelli, F., Preti, F., 2009. Multiple attribute decision making for individual tree detection using high-resolution laser scanning. Forest. Ecol. Manage. 258, 2501-2510.

García, M., Riaño, D., Chuvieco, E., Danson, F.M., 2010. Estimating biomass carbon stocks for a Mediterranean forest in central Spain using LiDAR height and intensity data. Rem. Sens. Environ. 114, 816-830.

Gaveau, D.L.A., Hill, R.A., 2003. Quantifying canopy height underestimation by laser pulse penetration in small-footprint airborne laser scanning data. Can. J. For. Res. 29, 650-657.

Hall, S.A., Burke, I.C., Box, D.O., Kaufmann, M.R., Stoker, J.M., 2005. Estimating stand structure using discrete-return lidar: an example from low density, fire prone ponderosa pine forests. Forest. Ecol. Manage. 208, 189-209.

Hill, R.A., Thomson, A.G., 2005. Mapping woodland species composition and structure using airborne spectral and LiDAR data. Int. J. Rem. Sens. 26, 3763-3779. 
Holmgren, J., Nilsson, M., Olsson, H., 2003. Estimation of tree height and stem volume on plots using airborne laser scanning. For. Sci. 49, 419-428.

Hopkinson, C., Chasmer, L.E., Sass, G., Creed, I.F., Sitar, M., Kalbfleisch, W., Treitz, P., 2005. Vegetation class dependent errors in LiDAR ground elevation and canopy height estimates in a boreal wetland environment. Can. J. For. Res. 31, 191-206.

Hyyppä, J., Inkinen, M., 1999. Detecting and estimating attributes for single trees using laser scanner. Photogramm. J. Fin. 16, 27-42.

Hyyppä, J., Kelle, O., Lehikoinen, M., Inkinen, M., 2001. A segmentation-based method to retrieve stem volume estimates from 3-d tree height models produced by laser scanners. IEEE Trans. Geosci. Remote. Sens. 39, 969-975.

Hyyppä, J., Hyyppä, H., Leckie, D., Gougeon, F., Yu, X., Maltamo, M., 2008. Review of methods of small-footprint airborne laser scanning for extracting forest inventory data in boreal forests. Int. J. Rem. Sens. 29, 1339-1366.

Kim, Y., Yang, Z., Cohen, W.B, Pflugmacher, D., Lauver, C.L., Vankat, J.L., 2009. Distinguishing between live and dead standing tree biomass on the North Rim of Grand Canyon National Park, USA using small-footprint LiDAR data. Rem. Sens. Environ. $113,2499-2510$.

Lefsky, M.A., Cohen, W.B., Acker, S.A., Parker, G., Spies, T., Harding, D., 1999. LiDAR remote sensing of the canopy structure and biophysical properties of Douglasfir western hemlock forests. Rem. Sens. Environ., 70, 339-361.

Li, Y., Andersen, H.-E., McGaughey, R., 2008. A comparison of statistical methods for estimating forest biomass from light detection and ranging data. West. J. Applied. For. $23,223-231$. 
Loudermilk, E.L., Hiers, J.K, O’Brien, J.J, Mitchell, R.J., Singhania, A., Fernandez, J.C., Cropper, W.P., Slatton, K.C., 2009. Ground-based LIDAR: a novel approach to quantify fine-scale fuelbed characteristics. Int. J. Wildland Fire 18, 676-685.

Maltamo, M., Eerikäinen, K., Pitkänen, J., Hyyppä, J., Vehmas, M., 2004. Estimation of timber volume and stem density based on scanning laser altimetry and expected tree size distribution functions. Rem. Sens. Environ. 90, 319-330.

Martinuzzi S., Vierling, L.A., Gould, W.A., Falkowski, M.J., Evans, J.S., Hudak, A.T., Vierling, K.T., 2009. Mapping snags and understory shrubs for a LiDAR-based assessment of wildlife habitat suitability. Rem. Sens. Environ. 113, 2533-2546.

Meng, X., Currit, N., Zhao, K., 2010. Ground filtering algorithms for airborne LiDAR data: a review of critical issues. Rem. Sens. 2, 833-860.

Mikšys, V., Varnagiryte-Kabasinskiene, I., Stupak, I., Armolaitis, K., Kukkola, M., Wójcik, J., 2007. Above-ground biomass functions for Scots pine in Lithuania. Biomass and Bioenergy 31, 685-692.

Mundt, J.T., Streutker, D.R., Glenn, N.F., 2006. Mapping sagebrush distribution using fusion of hyperspectral and LiDAR classifications. Photogramm. Eng. Rem. Sens. 72, 47-54.

Mutlu, M., Popescu, S.C., Zhao, K., 2008. Sensitivity analysis of fire behavior modeling with LIDAR-derived surface fuel maps. Forest. Ecol. Manage. 256, 289-294.

Næsset E., 2004. Accuracy of forest inventory using airborne laser scanning: evaluating the first nordic full-scale operational project. Scand. J. For. Res. 19, $554-557$.

Nelson, R., Krabill, W., Tonelli, J. 1998. Estimating forest biomass and volume using airborne LiDAR data. Rem. Sens. Environ. 24, 247-267.

Nelson, R., Short, A., Valenti, M., 2004. Measuring biomass and carbon in delaware using an airborne profiling LiDAR. Scand. J. For. Res. 19, 500-511. 
Pascual, C., García-Abril, A., García-Montero, L.G., Martín-Fernández, S., Cohen, W.B., 2008. Object-based semi-automatic approach for forest structure characterization using lidar data in heterogeneous Pinus sylvestris stands. Forest. Ecol. Manage. 255, $3677-3685$

Persson, A., Holmgren, J., Söderman, U., 2002. Detecting and measuring individual trees using an airborne laser scanner. Photogramm. Eng. Rem. Sens. 68, 925-932.

Popescu S.C., Wynne R.H., Nelson R.F., 2002. Estimating plot-level tree heights with LiDAR: local filtering with a canopy-height based variable window size. Comput. Electron. Agr. 37,71-95.

Popescu, S.C., 2007. Estimating biomass of individual pine trees using airborne LiDAR. Biomass and Bioenergy 31, 646-655.

Rango, A., Chopping, M., Ritchie, J., Havstad, K., Kustas, W., Schmugge, T., 2000. Morphological characteristics of shrub coppice dunes in desert grasslands of southern New Mexico derived from scanning LIDAR. Rem. Sens. Environ.74, 26-44.

Riaño, D., Chuvieco, E., Ustin, S.L., Salas, J., Rodríguez-Pérez, J.R., Ribeiro, L.M., Viegas, D.X., Moreno, J.M., Fernández, H., 2007. Estimation of shrub height for fueltype mapping combining airborne LiDAR and simultaneous color infrared ortho imaging. Int. J. Wildland Fire 16, 341-348.

Streutker, D.R., Glenn, N.F., 2006. LiDAR measurement of sagebrush steppe vegetation heights. Rem. Sens. Environ. 102, 135-145.

Su, J.G., Bork, E.W., 2006. Influence of vegetation, slope, and LiDAR sampling angle on DEM accuracy. Photogramm. Engin. Rem. Sens. 72, 1265-1274.

Su, J.G., Bork, E.W., 2007. Characterization of diverse plant communities in Aspen Parkland rangeland using LiDAR data. Appl.Veg. Sci. 10, 407-416. 
Takhtajan, A., 1986. Floristic regions of the world. Los Ángeles. University of California Press.

van Aardt, J.A.N., Wynne, R.H., Oderwald, R.G., 2006. Forest volume and biomass estimation using small-footprint LiDAR-distributional parameters on a per-segment basis. For. Sci. 52, 636-649.

Velázquez-Martí～B., Fernández-González, E., Estornell, J., Ruiz, L.A., 2010. Dendrometric and dasometric analysis of the bushy biomass in Mediterranean forests. Forest. Ecol. Manage. 259, 875-882.

Zheng, D., Rademacher, J., Chen, J., Crow, T., Bresee, M., Le Moine, J., Ryu, S-R., 2004. Estimating aboveground biomass using Landsat 7 ETM+ data across a managed landscape in northern Wisconsin, USA. Rem. Sens. Environ. 93, 402-411.

Zimble, D.A., Evans, D.L., Carlson, G.C., Parker, R.C., Grado, S.C, Gerard, P.D., 2003. Characterizing vertical forest structure using small-footprint airborne LiDAR. Rem. Sens. Environ. 87, 171-82. 